Late Pleistocene glacial stratigraphy of the Kumara-Moana region, West Coast of South Island, New Zealand

\title{
Barrows, TT
}

http://hdl.handle.net/10026.1/5359

\subsection{6/j.quascirev.2013.04.010 \\ Quaternary Science Reviews}

All content in PEARL is protected by copyright law. Author manuscripts are made available in accordance with publisher policies. Please cite only the published version using the details provided on the item record or document. In the absence of an open licence (e.g. Creative Commons), permissions for further reuse of content should be sought from the publisher or author. 


\section{A White Nile Megalake during the last interglacial period.}

Timothy T. Barrows*
Department of Geography, College of Life and Environmental Science, University of Exeter, Exeter, Devon, EX4 4RJ, United Kingdom

\section{Martin A. J. Williams}

Geography, Environment \& Population, University of Adelaide, Adelaide, SA 5005, Australia.

\section{Stephanie C. Mills}

School of Geography, Geology and the Environment, Centre for Earth \& Environmental Science Research, Kingston University London, Kingston upon Thames KT1 2EE, United Kingdom

\section{Geoff A. T. Duller}

Institute of Geography and Earth Sciences, University of Aberystwyth, Aberystwyth, Ceredigion $S Y 233 D B, U K$

\section{Keith Fifield}

Department of Nuclear Physics, Research School of Physics and Engineering, The Australian National University, Canberra, ACT 0200 Australia

\section{David Haberlah}

Geology and Geophysics,, University of Adelaide, Adelaide, SA 5005, Australia.

\section{Stephen G. Tims}

Department of Nuclear Physics, Research School of Physics and Engineering, The Australian National University, Canberra, ACT 0200 Australia

\section{Frances M. Williams}

Luminescence Dating Laboratory, School of Chemistry and Physics, University of Adelaide, Adelaide, 5005, Australia

This manuscript is the final submitted version and contains errors that were corrected during proofing. To access the published version, please see: http://geology.gsapubs.org/ 
41 The eastern Sahara Desert is one of the most climatically sensitive areas on Earth, varying from

42 lake-studded savanna woodland to hyper-arid desert over the course of a glacial-interglacial

43 cycle. In presently arid Sudan there is widespread evidence that a very large freshwater lake once

44 filled the White Nile River valley. Here we present the first quantitative estimate for the

45 dimensions of the lake and a direct age for the emplacement of one of the shorelines. Using a

46 profile dating approach with the cosmogenic nuclide ${ }^{10} \mathrm{Be}$, we estimate an exposure age of $109 \pm$

$478 \mathrm{ka}$ for this megalake, indicating it formed during the last interglacial period. This age is

48 supported by optically stimulated luminescence dating of Blue Nile palaeochannels associated

49 with the lake. Using a high-resolution digital elevation model we estimate that the lake was more

50 than $45,000 \mathrm{~km}^{2}$ in area, making it comparable to the largest freshwater lakes on Earth today. We

51 attribute the lake's existence to seasonal flood pulses as a result of local damming of the White

52 Nile by a more southerly position of the Blue Nile and greatly increased precipitation associated

53 with a super monsoon. 
INTRODUCTION

The Nile is the longest river in the world and its basin extends over $\sim 3$ million $\mathrm{km}^{2}$

58 (Figure 1a). Geomorphic records show that the flow of the White Nile has varied dramatically

59 through time as a result of climate change (Williams et al., 2010). These changes in flow have

60 had a profound impact on the environment and the habitability of the lower basin. Since at least

61 the middle Pleistocene the Nile has acted as a corridor for human dispersal and a refuge during

62 periods of aridity (Basell, 2008). The occurrence of warmer, wetter conditions after the last

63 glacial maximum (Gasse, 2000) coincides with the advent of Neolithic farming in the Nile valley

64 and the emergence of one of the world's great urban civilizations in Egypt (Kuper and Kröpelin, 65 2006).

Sudan was much wetter in the early Holocene than at present, with lakes in the Sahara

67 Desert between $\sim 9500$ and $4500{ }^{14} \mathrm{C}$ yr BP (Hoelzmann et al., 2000). At this time the Nile

68 flooded up to $5 \mathrm{~m}$ above modern river levels forming a lake 20-40 km wide (Williams et al.,

69 2006). Above the Holocene flood level, the presence of a prominent shoreline led Williams et al.

70 (2003) to propose the presence of an even larger lake. In order to maintain a large lake in Sudan,

71 major shifts in regional atmospheric circulation are required (Williams et al., 2003). Attempts

72 have been made to date this White Nile megalake. However, the age remains ambiguous, with

73 estimates ranging from the Holocene back to $400 \mathrm{ka}$ (Williams et al., 2003; Williams et al., 74 2010).

\section{EXPOSURE DATING AND OPTICALLY STIMULATED LUMINESCENCE}

Given the possible maximum age of the shoreline, we chose to exposure date deposition

77 of the shoreline using the cosmogenic nuclide ${ }^{10} \mathrm{Be}$, which can provide age constraints beyond 78 the limits of radiocarbon and luminescence techniques. Samples for dating were collected from a 
79 shoreline on a well-preserved cuspate foreland near Jebelein in south-central Sudan (Site A Fig.

80 1B; Supplemental Table S1). The shoreline lies $\sim 20 \mathrm{~m}$ above the modern Nile River at $\sim 400 \mathrm{~m}$ at

$8112.6^{\circ} \mathrm{N}$. An original survey used the old Alexandria datum and gave an elevation of $386 \mathrm{~m}$ for

82 the break in slope at the edge of the shoreline (Williams et al., 2003). The gravel and coarse sand

83 constituting the shoreline is locally derived from weathering of granite inselbergs adjacent to the

84 Nile River, subsequently transported by longshore drift. Wave action has worked the weathered

85 gravel, which is highly rounded (Fig. 2). The shoreline has a typical width of $600 \mathrm{~m}$ and only

86 extends about $10 \mathrm{~km}$ to the north and south of the inselbergs. We also sampled the summit of the

87 nearest inselberg, Jebel Hawaja, to estimate likely ${ }^{10} \mathrm{Be}$ inheritance in the gravel.

To associate the shoreline formation with contemporary channel development along the

89 Nile, we applied optically stimulated luminescence at three sites further north. A series of former

90 Blue Nile channels radiate northwest across the alluvial plain west of the Blue Nile towards the

91 White Nile and coincide with the northern limit of the lake (Williams, 2009) (Fig. 1B). The first

92 site dated (Site B) is located on a palaeochannel on the east bank of the White Nile. Site C is on

93 the clay floodplain of another channel between a large north-south aligned sand dune and the

94 White Nile. This channel can be traced laterally northwest on aerial photographs until it runs

95 beneath the linear dune on its path towards the White Nile. The site B sands may be part of this

96 same channel complex. Site D is located on the east bank of the current Blue Nile Channel above

97 its current level (Fig. 3).

\section{$98 \quad$ RESULTS}

99 The ${ }^{10} \mathrm{Be}$ concentration in the depth profile decreases with depth as expected (Fig. 2;

100 Table S2). The exception is the surface sample, which has a lower ${ }^{10} \mathrm{Be}$ concentration than

101 expected because of bioturbation, and the resultant curve fit is poor $\left(\chi^{2} / v=2.7\right)$. Excluding the 
102 surface sample greatly improves the quality of the fit and the uncertainties are consistent with the

103 curve fit $\left(\chi^{2} / v=0.76\right)$. The best-fit age is $109 \pm 8 \mathrm{ka}$. The quality of the fit indicates minimal

104 removal from or addition of sediment to the profile through time.

105 Under the assumption of steady state erosion, the three analyses from Jebel Hawaja

106 indicate that it is lowering at a rate of $1-5 \mathrm{~m} / \mathrm{Ma}$ (Table 2), typical of desert inselbergs (e.g.

107 (Bierman and Caffee, 2002)). The range in these values is likely to be due to the varying degrees

108 of exfoliation observed across the summit. Sediment derived from this surface is therefore likely

109 to have a significant ${ }^{10} \mathrm{Be}$ inheritance. The ${ }^{10} \mathrm{Be}$ concentrations represent a maximum for

110 sediment being generated from the inselberg; the steep, shielded, higher surface area flanks will

111 contain lower concentrations of ${ }^{10} \mathrm{Be}$. The inherited component from the curve fit in the section is

112303,500 atoms/g, consistent with weathering from the Jebel once the steep shielded flanks are

113 taken into account.

114 The OSL ages on channel sands at site B indicate a prolonged phase of fluvial sand 115 entrainment and deposition in this area between about 100 and 70 ka ago (Fig. 3; Table S3). At

116 site $\mathrm{C}$ the floodplain clays were deposited in the late Pleistocene and early Holocene after the

117 resumption of the African Monsoon (Williams et al., 2006). The underlying well-sorted fluvial

118 sand was deposited during the last interglacial period at the same time as the sand at the base of

119 Site B. Site D has an age similar to the base of the other two sections and indicates high-energy

120 flow at $104 \mathrm{ka}$ at the site of the modern Blue Nile Channel.

121 Based on SRTM90 data, the White Nile Megalake at its maximum level would have

122 extended as far north as $15^{\circ} \mathrm{N}$ with a length of $650 \mathrm{~km}$, a maximum width of $80 \mathrm{~km}$, an average

123 depth of $6 \mathrm{~m}$, and an area of $45,000 \mathrm{~km}^{2}$ (see also supplemental methods). This lake area is likely

124 to be a minimum because of progradation by the extensive Khor Abu Habl alluvial fan and 
125 encroachment of the linear dunes of the Sahara Desert formed before and during the last glacial

126 maximum, both of which have partially blocked the valley. The maximum depth above the

127 Holocene floodplain in the middle of the lake is $\sim 12 \mathrm{~m}$, which does not take into account

128 Holocene sedimentation. The lake extends $150 \mathrm{~km}$ further south than proposed by Williams et al.

129 (2003) and the volume would have been $\sim 270 \mathrm{~km}^{3}$, which is more than twice the amount

130 previously estimated by Williams et al. (2003).

\section{DISCUSSION}

132 The age of the White Nile Megalake shoreline dates the origin of the White Nile River

133 back to at least the last interglacial period. The reconstructed dimensions of the 'lake' would

134 make the White Nile at that time the widest river on Earth, and would currently rank it one of the

135 four largest lakes by area. The presence of a significant shoreline only on the eastern side of the

136 White Nile suggests that the lake was only full during the summer months of the monsoon when

137 southwesterly winds delivered rain from inner Africa and there was much greater flow into the

138 White Nile from the Ugandan lakes. The optical ages indicate at least two channels of the Blue

139 Nile were active at the same time, delivering large volumes of discharge.

140 The setting for such a large lake occupying a broad and shallow river valley without an 141 obvious dam is highly unusual on Earth today. The lack of a prominent shoreline north of Esh

142 Shawal $\left(13^{\circ} 30^{\prime} \mathrm{N}\right)$ corresponds to three important morphological features which could

143 contribute to the damming of a lake. First, the major linear dune field from the west impinges on

144 the river from $\sim 13-14^{\circ} \mathrm{N}$ (Figure $1 \mathrm{~b}$ ) and was probably present in some form before the last

145 glacial maximum. This sheet of sand partially fills the eastern side of the valley and forces the

146 White Nile up against the Managil Ridge. Second, the White Nile valley narrows north of $14^{\circ} \mathrm{N}$,

147 which acts to constrict the flow of the river. Third, the Blue Nile joins the White Nile at $15^{\circ} 36^{\prime}$ 
148 N. When the unregulated Blue Nile was in flood in modern times, the flood pulse of the Blue

149 Nile resulted in damming of the White Nile for $300 \mathrm{~km}$ up the valley to create a lake up to $3 \mathrm{~km}$

150 wide near its northern end (Willcocks, 1904). With completion in 1935 of the Jebel Aulia dam

151 (Fig. 1b) on the White Nile $35 \mathrm{~km}$ upstream of Khartoum, the reservoir when full also produces a

152 body of slack water that extends $\sim 300 \mathrm{~km}$ upstream.

153 Our dating of the Blue Nile palaeochannels indicates that the third factor was much more

154 significant during the last interglacial period than at present. A major late Pleistocene

155 palaeochannel of the Blue Nile joined the White Nile near Naima and El Geteina (Fig. 1b), 120

$156 \mathrm{~km}$ and $80 \mathrm{~km}$ south of the modern confluence, respectively (Williams, 2009) and our dating

157 demonstrates that the channel development and flooding were contemporaneous. Given

158 enhanced flow from both the Blue and the White Nile at this time, it is likely that the Blue Nile

159 floods could have acted to dam the White Nile to an elevation of $400 \mathrm{~m}$. Much higher flow than

160 present is suggested by the age at Site D, indicating a distributary was also active (probably

161 during peak flooding) at this time near the site of the present Blue Nile.

The climate must have been significantly more humid during the last interglacial period

163 in order for such a large lake to persist in the White Nile valley. Sudan is presently arid, with

164 mean annual rainfall decreasing northwards from $780 \mathrm{~mm}$ at Malakal in the south to $140 \mathrm{~mm}$ at

165 Khartoum (Hijmans et al., 2005), reflecting limited transport of moisture northward during the

166 modern southwest monsoon. Pan evaporation rates increase northwards from $2000 \mathrm{~mm} / \mathrm{yr}$ at

167 Malakal to nearly $4000 \mathrm{~mm} / \mathrm{yr}$ at Khartoum (Shahin, 1985). Modern evaporation rates on a lake

168 of $45,000 \mathrm{~km}^{2}$ would amount to a total of $63,-95,000 \mathrm{~km}^{3} / \mathrm{yr}$ on a lake with a volume of only 270

$169 \mathrm{~km}^{3}$. Modern day flow is only $\sim 27 \mathrm{~km}^{3} / \mathrm{yr}$ at the southern end of the lake (Williams et al., 2003)

170 and modern precipitation on the lake would be $\sim 21 \mathrm{~km}^{3} / \mathrm{yr}$, indicating that it would not be 
171 possible to form the lake under conditions similar to the present. Ignoring lake outflow, flow

172 would need to triple or have a major contribution from the Blue Nile flood pulse, and on-lake

173 precipitation increase by $50 \%$ just to start filling the lake, provided increased cloudiness and

174 humidity led to a concomitant drop in evaporation to levels characteristic of the humid south of 175 Sudan.

The presence of a White Nile Megalake adds to an emerging picture that during the last 177 interglacial period the Sahara Desert was an oasis-studded savanna hosting Middle Paleolithic 178 hunter-gatherers (Wendorf et al., 1993). Identifying large lakes present during this period has 179 been hampered by difficulties in dating (Geyh and Thiedig, 2008). (Armitage et al., 2007) have 180 determined a possible high lake phase in the middle of the last interglacial period at $100-110 \mathrm{ka}$ 181 for Lake Megafazzan in the Libyan Desert based on OSL ages from coquinas. A slightly later 182 age of 95ka has been suggested as representing a humid phase in the western Sahara Desert, 183 based on uranium-series dating of lake sediments (Causse et al., 1988). Deep sea cores taken off 184 the west coast of Africa show that during the last interglacial period the climate was more humid 185 in North Africa because there were low inputs from dust (Moreno et al., 2001) and high river 186 flow (Weldeab et al., 2007). Further confirmation of high fluvial flow comes from deep sea cores collected from the 188 floor of the eastern Mediterranean which show a repetitive sequence of alternating calcareous 189 muds with a significant content of Saharan wind-blown dust, and dark organic-rich sediments, 190 termed sapropels (Ducassou et al., 2008; Larrasoaña et al., 2003). These sapropel units are 191 thought to have accumulated during times of enhanced freshwater inflow from the Nile and now 192 inactive Saharan rivers (Osborne et al., 2008; Scrivner et al., 2004; Wehausen and Brumsack, 193 1998). The White Nile Megalake probably formed during Sapropel Unit 5 (S5) (Kroon et al., 
194 1998; Lourens et al., 1996). Based on these sapropel units, (Rohling et al., 2002) have suggested 195 that the Intertropical Convergence Zone (ITCZ) penetrated seasonally approximately $21^{\circ} \mathrm{N}$ 196 during the last interglacial period. Global Circulation Models (GCMs) support this finding 197 (Kutzbach and Liu, 1997). The Indian Ocean monsoonal rainfall reached as far north as northern 198 Sudan during the Holocene pluvial phase (Rodrigues et al., 2000), which is thought to have been 199 of lesser magnitude than during the last interglacial (de Noblet et al., 1996).

200 The only feasible way to maintain a lake the size of the White Nile Megalake in south201 central Sudan is though intensification of the African Monsoon and its increased penetration into 202 northern Africa. The last interglacial period coincided with a very strong northern hemisphere 203 solar insolation maximum, which greatly enhanced the intensity of the summer monsoon in the 204 northern hemisphere (Rossignol-Strick, 1983). This super monsoon occurred at a time when sea 205 level likely exceeded $8 \mathrm{~m}$ higher than present (Rohling et al., 2008) and mean temperatures were 206 up to $2{ }^{\circ} \mathrm{C}$ higher than present. The accompanying increased precipitation was capable of 207 transforming this section of the Sahara into a wet, vegetated landscape. 


\section{ACKNOWLEDGEMENTS}

211 We thank three anonymous reviewers of an earlier draft for their constructive

212 suggestions. We thank the Australian Research Council for financial support (grant DP0878058

213 to MAJW) and the Geological Research Authority of the Sudan for logistical support. Sayed

214 Nagi Abdalla Mohamed, Field Manager, Danfodia Company for Contracting Roads and Bridges,

215 Jebelein, generously allowed the use of a bulldozer for excavating the trench at site A. 
REFERENCES

\section{References}

Armitage, S. J., Drake, N. A., Stokes, S., El-Hawat, A., Salem, M. J., White, K., Turner, P., and McLaren, S. J., 2007, Multiple phases of North African humidity recorded in lacustrine sediments from the Fazzan Basin, Libyan Sahara: Quaternary Geochronology, v. 2, no. 14, p. 181-186.

Basell, L. S., 2008, Middle Stone Age (MSA) site distributions in eastern Africa and their relationship to Quaternary environmental change, refugia and the evolution of Homo sapiens: Quaternary Science Reviews, v. 27, no. 27-28, p. 2484-2498.

Bierman, P. R., and Caffee, M., 2002, Cosmogenic exposure and erosion history of Australian bedrock landforms: Geological Society of America Bulletin, v. 114, no. 7, p. 787-803.

Causse, C., Conrad, G., Fontes, J.-C., Gasse, F., Gibert, E., and Kassir, A., 1988, Le dernier "Humide" pléistocène du Sahara nord-occidental daterait de 80-100 000 ans: Comptes rendus de l'Académie des Sciences (Série II), v. 306, p. 1459-1464.

de Noblet, N., Braconnot, P., Joussaume, S., and Masson, V., 1996, Sensitivity of simulated Asian and African summer monsoons to orbitally induced variations in insolation 126, 115 and 6 kBP: Climate Dynamics, v. 12, no. 9, p. 589-603.

Ducassou, E., Mulder, T., Migeon, S. b., Gonthier, E., Murat, A., Revel, M., Capotondi, L., Bernasconi, S. M., Mascle, J., and Zaragosi, S. b., 2008, Nile floods recorded in deep Mediterranean sediments: Quaternary Research, v. 70, no. 3, p. 382-391.

Gasse, F., 2000, Hydrological changes in the African tropics since the Last Glacial Maximum: Quaternary Science Reviews, v. 19, no. 1-5, p. 189-211.

Geyh, M. A., and Thiedig, F., 2008, The Middle Pleistocene Al Mahrúqah Formation in the Murzuq Basin, northern Sahara, Libya evidence for orbitally-forced humid episodes during the last 500,000 years: Palaeogeography, Palaeoclimatology, Palaeoecology, v. 257, no. 1-2, p. 1-21.

Hijmans, R. J., Cameron, S. E., Parra, J. L., Jones, P. G., and Jarvis, A., 2005, Very high resolution interpolated climate surfaces for global land areas: International Journal of Climatology, v. 25, no. 15, p. 1965-1978.

Hoelzmann, P., Kruse, H.-J., and Rottinger, F., 2000, Precipitation estimates for the eastern Saharan palaeomonsoon based on a water balance model of the West Nubian Palaeolake Basin: Global and Planetary Change, v. 26, no. 1-3, p. 105-120.

Kroon, D., Little, A. M., Lourens, L. J., Matthewson, A., Robertson, A. H. F., and Sakamoto, T., 1998, Oxygen isotope and sapropel stratigraphy in the Eastern Mediterranean during the last 3.3 million years, in Robertson, A. H. F., Emeis, K.-C., Richter, C., and Camerlengui, A., eds., Proceedings of the Ocean Drilling Program, Scientific Results, Volume 160, p. 181-189.

Kuper, R., and Kröpelin, S., 2006, Climate-Controlled Holocene Occupation in the Sahara: Motor of Africa's Evolution: Science, v. 313, no. 5788, p. 803-807.

Kutzbach, J. E., and Liu, Z., 1997, Response of the African Monsoon to Orbital Forcing and Ocean Feedbacks in the Middle Holocene: Science, v. 278, no. 5337, p. 440-443.

Larrasoaña, J. C., Roberts, A. P., Rohling, E. J., Winklhofer, M., and Wehausen, R., 2003, Three million years of monsoon variability over the northern Sahara: Climate Dynamics, v. 21, no. 7 , p. 689-698. 
Lourens, L. J., Antonarakou, A., Hilgen, F. J., Van Hoof, A. A. M., Vergnaud-Grazzini, C., and Zachariasse, W. J., 1996, Evaluation of the Plio-Pleistocene Astronomical Timescale: Paleoceanography, v. 11, no. 4, p. 391-413.

Moreno, A., Targarona, J., Henderiks, J., Canals, M., Freudenthal, T., and Meggers, H., 2001, Orbital forcing of dust supply to the North Canary Basin over the last $250 \mathrm{kyr}$ : Quaternary Science Reviews, v. 20, no. 12, p. 1327-1339.

Osborne, A. H., Vance, D., Rohling, E. J., Barton, N., Rogerson, M., and Fello, N., 2008, A humid corridor across the Sahara for the migration of early modern humans out of Africa 120,000 years ago: Proceedings of the National Academy of Sciences, v. 105, no. 43, p. 16444-16447.

Rodrigues, D., Abell, P. I., and Kröpelin, S., 2000, Seasonality in the early Holocene climate of Northwest Sudan: interpretation of Etheria elliptica shell isotopic data: Global and Planetary Change, v. 26, no. 1-3, p. 181-187.

Rohling, E. J., Cane, T. R., Cooke, S., Sprovieri, M., Bouloubassi, I., Emeis, K. C., Schiebel, R., Kroon, D., Jorissen, F. J., Lorre, A., and Kemp, A. E. S., 2002, African monsoon variability during the previous interglacial maximum: Earth and Planetary Science Letters, v. 202, no. 1, p. 61-75.

Rohling, E. J., Grant, K., Hemleben, C., Siddall, M., Hoogakker, B. A. A., Bolshaw, M., and Kucera, M., 2008, High rates of sea-level rise during the last interglacial period: Nature Geosci, v. 1, no. 1, p. 38-42.

Rossignol-Strick, M., 1983, African monsoons, an immediate climate response to orbital insolation: Nature, v. 304, no. 5921, p. 46-49.

Scrivner, A. E., Vance, D., and Rohling, E. J., 2004, New neodymium isotope data quantify Nile involvement in Mediterranean anoxic episodes: Geology, v. 32, no. 7, p. 565-568.

Shahin, M., 1985, Hydrology of the Nile Basin: Developments in Water Science, v. Volume 21, p. 575.

Wehausen, R., and Brumsack, H.-J., 1998, The formation of Pliocene Mediterranean sapropels: Constraints from high-resolution major and minor element studies, in Robertson, A. H. F., Emeis, K.-C., Richter, C., and Camerlengui, A., eds., Proceedings of the Ocean Drilling Program, Scientific Results, Volume 160, p. 207-217.

Weldeab, S., Lea, D. W., Schneider, R. R., and Andersen, N., 2007, 155,000 Years of West African Monsoon and Ocean Thermal Evolution: Science, v. 316, no. 5829, p. 13031307.

Wendorf, F., Schild, R., and Close, A., 1993, Egypt During the Last Interglacial: The Middle Paleolithic of Bir Tarfawi and Bir Sahara East: New York, Plenum, p. 596

Willcocks, W., 1904, The Nile in 1904, London, E. \& F. N. Spon Ltd, 225 p p.:

Williams, M., Talbot, M., Aharon, P., Abdl Salaam, Y., Williams, F., and Inge Brendeland, K., 2006, Abrupt return of the summer monsoon 15,000 years ago: new supporting evidence from the lower White Nile valley and Lake Albert: Quaternary Science Reviews, v. 25, no. 19â€"'20, p. 2651-2665.

Williams, M. A. J., 2009, Late Pleistocene and Holocene environments in the Nile basin: Global and Planetary Change, v. 69, no. 1-2, p. 1-15.

Williams, M. A. J., Adamson, D., Prescott, J. R., and Williams, F. M., 2003, New light on the age of the White Nile: Geology, v. 31, no. 11, p. 1001-1004.

Williams, M. A. J., Williams, F. M., Duller, G. A. T., Munro, R. N., El Tom, O. A. M., Barrows, T. T., Macklin, M., Woodward, J., Talbot, M. R., Haberlah, D., and Fluin, J., 2010, Late 
Quaternary floods and droughts in the Nile valley, Sudan: new evidence from optically stimulated luminescence and AMS radiocarbon dating: Quaternary Science Reviews, v. 29, no. 9-10, p. 1116-1137. 


\section{FIGURES}

\section{Figure 1}

316 a) The catchment of the Nile River, b) reconstruction of the White Nile Megalake in Sudan, and

317 c) a section of the eastern shoreline showing the sample location and cuspate forelands.

\section{Figure 2}

319 a) Section log of the sampled profile at Site A. Soil development was strong on the section and 320 the colour was dark brown at the surface, grading to orange red below $1.3 \mathrm{~m}, \mathrm{~b}$ ) Approximate 321 breakdown of size classes for the sediment. Note the low concentration of very fine sediment in 322 the soil, and c) ${ }^{10} \mathrm{Be}$ concentrations in the measured samples together with least squares fit to the 323 data, excluding the surface sample. Note the asymptotic decline of the curve indicating a 324 significant inherited component.

\section{$325 \quad$ Figure 3}

326 Section logs at Sites B-D. At site D, the sands contained abundant fossils, including a probable 327 rhinoceros femur, three broken pieces of a tree trunk 0.6 to $1.0 \mathrm{~m}$ in diameter and $4.05 \mathrm{~m}$ long, 328 entirely replaced by crystalline calcite, abundant silicified fragmentary mammal bones, horn 329 cores, and Nile oyster shells (Etheria elliptica). The gravel forms a low terrace flooded during 330 the Blue Nile floods, preserved from erosion because of carbonate cement. 
Figure 1

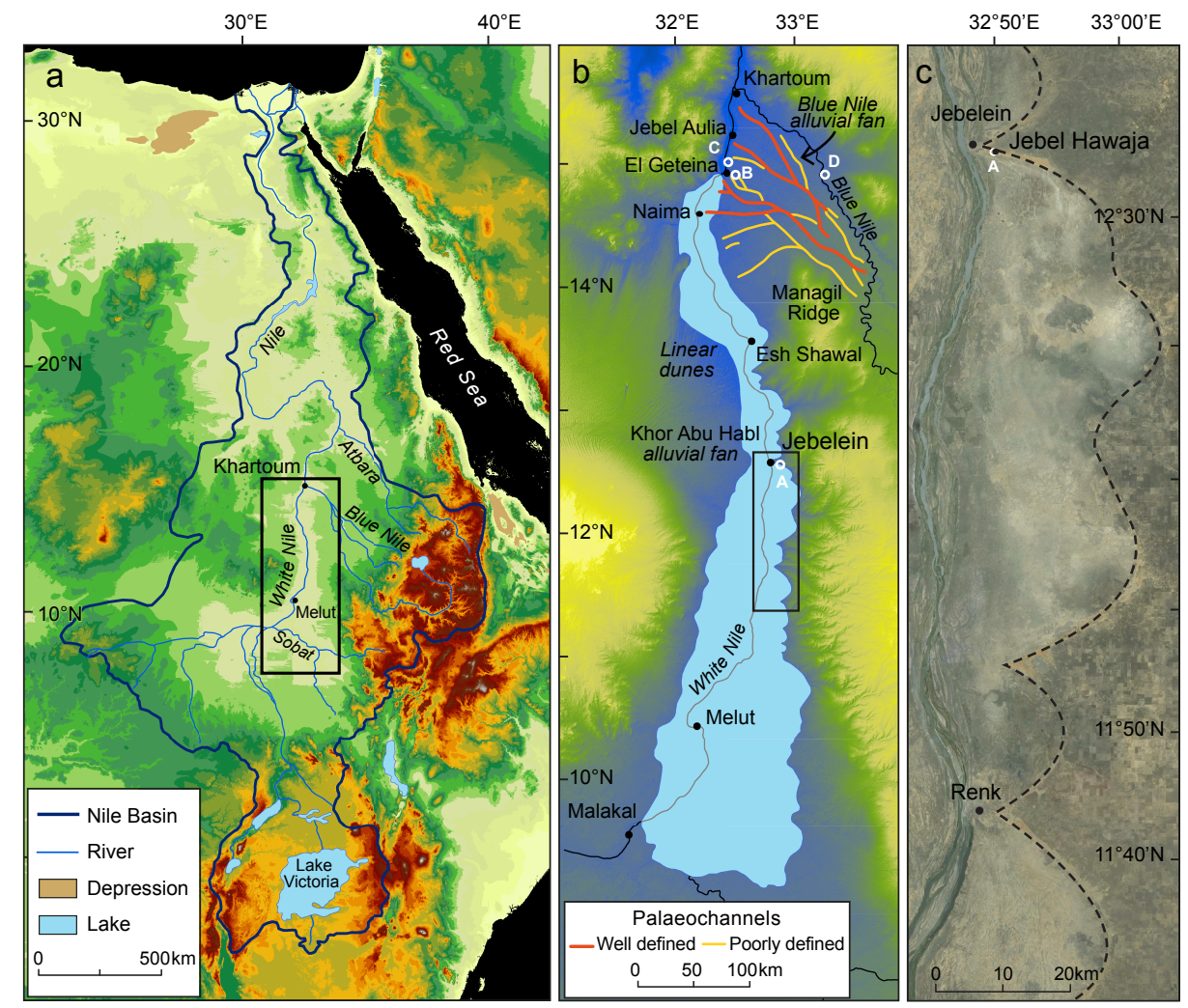


Figure 2

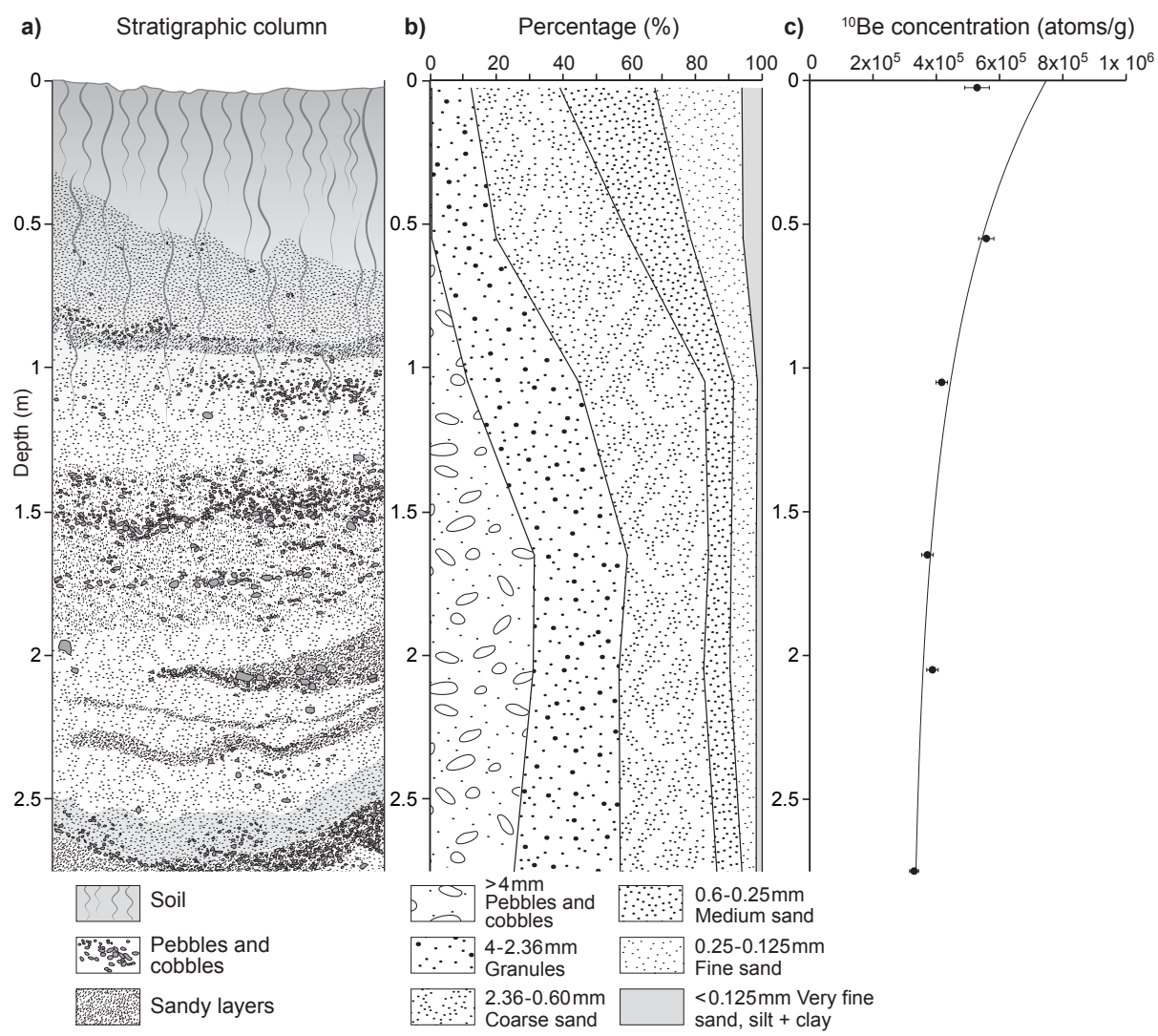


Figure 3

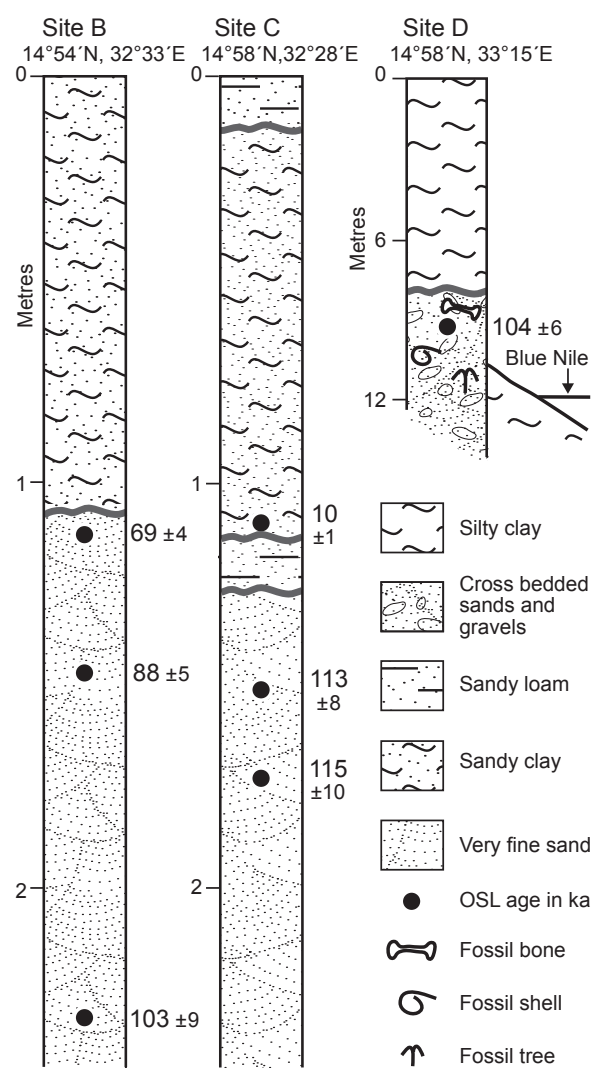




\section{SUPPLEMENTAL METHODS}

\section{EXPOSURE DATING}

To sample the shoreline we selected a site about $280 \mathrm{~m}$ west of the nearest inselberg (Jebel Hawaja; Figure 2) to reduce the possibility of slope wash reaching the sample site. Aerial images show slope wash halos around the inselbergs and a post-depositional alluvial fan $2 \mathrm{~m}$ thick flanking the inselberg and extending over the adjacent shoreline to at least 100 m. A 3 m trench (Section S2 of Williams et al. (2010)) was excavated using a bulldozer and 6 samples were collected at $0.5 \mathrm{~m}$ intervals down the pit wall. Field observations and particle size analysis at site S2 (Figure 2) show a decrease in gravel content and an increase in sand from the base upwards, consistent with lake retreat, a decrease in wave energy and final deposition of a sandy beach at the site. A well developed soil has subsequently formed on top of the shoreline sediment.

The granite was crushed and a coarse quartz concentrate was prepared using heavy liquids and magnetic separation. Only the coarse sand $(>0.5 \mathrm{~cm})$ and gravel fraction of the shoreline sediment was used for ${ }^{10} \mathrm{Be}$ analysis. We purified quartz and extracted ${ }^{10} \mathrm{Be}$ using standard methods (Barrows et al., 2001). The surface sample was run in duplicate. Isotopic ratios $\left({ }^{10} \mathrm{Be} / \mathrm{Be}\right)$ were measured by accelerator mass spectrometry on the $14 \mathrm{UD}$ accelerator at the Australian National University.

To investigate the potential for sequential deposition of the shoreline and to quantify inheritance of cosmogenic nuclides in the sand and gravel, we used a profile dating approach. Prolonged exposure of a sediment column to cosmic rays produces a characteristic cosmogenic nuclide depth profile that is a function of the production rate of the nuclide, sediment density, the accumulation or erosion rate of the sediment, and inherited nuclides in the sediment from previous exposure at the sediment source. Ideal conditions for exposure 
dating a profile are rapid deposition, an absence of post-depositional accumulation or erosion of the surface, and rapid erosion rates at the sediment source, which delivers a minimal inherited nuclide component. The setting of the Jebelein shoreline satisfies these suitability criteria. The ridge represents a high-energy depositional environment and therefore was deposited in a brief period of time. Second, there is no geomorphic evidence for widespread erosion of the surface in the form of gullying. Third, there appears to have been limited postdepositional accumulation of sediment on the surface. However, inheritance is likely to be significant because weathering rates are low on inselbergs in desert environments (e.g., Bierman and Caffee (2002)).

Cosmogenic nuclide production rates are a topic of active research and as yet no consensus has emerged as to a ${ }^{10} \mathrm{Be}$ production rate and a single scaling scheme that is globally applicable. The CRONUS calibration data set gives a ${ }^{10} \mathrm{Be}$ production rate by spallation of $4.49 \pm 0.39$ atom $\mathrm{g}^{-1} \mathrm{a}^{-1}$ at high latitude and sea level using the (Stone, 2000) scaling scheme (Balco et al., 2008). However, recent calibrations indicate that this rate is too high by at least 10\% (Balco et al., 2009; Fenton et al., 2011; Kaplan et al., 2011; Putnam et al., 2010). In the absence of a regional production rate calibration, we used the North American regional production rate of Balco et al. (2009) which is at a similar elevation $(<500$ m) and within uncertainties is the same as the other recent Northern hemisphere calibration (Fenton et al., 2011). It also has a longer calibration exposure age incorporating more geomagnetic variability. To scale the production rates we use the scaling scheme of (Lifton et al., 2005). Barrows et al. (2013) have shown that the Lifton et al. (2005) scheme produced the best match between ${ }^{10} \mathrm{Be}$ and radiocarbon dates in New Zealand. The calculated ${ }^{10} \mathrm{Be}$ concentrations, ages and weathering rates are given in Supplemental Table 2.

To determine the exposure age for the profile, we updated the coefficients of the equations used in Granger and Smith (2000) for the ${ }^{10} \mathrm{Be}$ production rate of Balco et al. 
50 (2009) from that of Stone (2000). Maximum likely inheritance on the gravel was determined by processing three samples from the top of the adjacent Jebel Hawaja. The morphology of the inselbergs at Jebelein, including exfoliation and solution pits, indicates a low long-term weathering rate.

The uppermost part of the section appears to be reworked. OSL dating of fine sand in the surface soil at a depth of $56 \mathrm{~cm}$ yielded an apparent age of 3.0-3.1 ka. Fine sand from 106 $\mathrm{cm}$ showed very high dispersion and had equivalent dose values at about $1.5 \mathrm{~Gy}$ and $120 \mathrm{~Gy}$, corresponding to ages between $2.0 \mathrm{ka}$ and $158 \mathrm{ka}$ (Williams et al., 2010). Additionally a portable dolerite murhakah (lower grinding stone) was found within the soil after excavation, but from an unknown depth. The age of this grindstone is difficult to determine because their use extends from the upper Palaeolithic through to the recent. Dozens of grinding holes and thick camp site hearth deposits of charcoal and broken bone line the edges of nearby inselbergs adjacent to the Nile River and indicate an important site of Neolithic habitation during a time when grassland was more widespread, probably before $4,500{ }^{14} \mathrm{C}$ yr BP. We therefore consider it likely that the grindstone was incorporated into the profile during the mid Holocene and therefore the upper part of the sediment profile was probably reworked at this time. It is also possible that some slope wash from the inselberg has reached the site and lowered the mean ${ }^{10} \mathrm{Be}$ concentration of the surface sediment. For these reasons we chose to analyse the coarse sand and gravel which has a much lower potential for translocation both up and down the profile. Our logging showed that original bedding of the coarse clasts is intact below the surface of the soil (Fig. 2).

We used the CRONUS online calculator (Balco et al. 2008) to calculate the ${ }^{10} \mathrm{Be}$ production rate at the site. The exposure age (together with inheritance) was calculated from 
capture and fast muons (Granger and Smith, 2000). Because the relative errors are similar on each sample, we did not weight the fit.

The density of the sediment varies through the profile and so it was not possible to determine an integrated mean density for use in the calculations. The density of sand and gravel mixtures ranges from $1.6-2.1 \mathrm{~g} / \mathrm{cm}^{3}$, so we chose a density of $1.9 \mathrm{~g} / \mathrm{cm}^{3}$. Variations of $0.1 \mathrm{~g} / \mathrm{cm}^{3}$ in density change the exposure age by $\sim 2 \%$. A density of $2.7 \mathrm{~g} / \mathrm{cm}^{3}$ was used for the granite samples. The quoted uncertainties are $68 \%$ confidence limits incorporating all known sources of measurement error, and include fully propagated production rate errors.

\section{OPTICALLY STIMULATED LUMINESCENCE}

Seven samples were collected for optically stimulated luminescence (OSL) dating from channel sands and overlying sediments, and one sample was collected from the modern White Nile to assess the extent to which the OSL signal is reset at deposition in this environment. Samples were collected by inserting an opaque tube into the sediment. This was then sealed at both ends and wrapped in black plastic. In the laboratory the material from both ends of the tube, which would have been exposed to light, was scraped out and used for environmental dose rate measurements.

Samples were processed either at Aberystwyth University or at the University of Adelaide. The comparability of the two sets of analysis has previously been demonstrated (Macklin et al., 2013). Samples were prepared using similar procedures in both laboratories. Samples were initially treated with hydrochloric acid to digest carbonates and hydrogen peroxide to remove any small amounts of organic material. Grains in the ranges $180-212 \mu \mathrm{m}$ (Aberystwyth) and 125-180 $\mu \mathrm{m}$ (Adelaide) were selected by dry sieving. Solutions of sodium polytungstate were used to isolate grains with a density between 2.62 and $2.70 \mathrm{~g} / \mathrm{cm}^{3}$. Grains were etched for 40 minutes in $40 \%$ hydrofluoric acid to remove feldspar and other non-quartz 
material and to remove the outer $9 \mu \mathrm{m}$ of the quartz grains. This eliminates the effect of alpha particle contribution to the irradiation of the grains. The material was then re-sieved to remove any remaining feldspar grains. All the laboratory procedures were carried out in subdued red light.

In Adelaide, uranium (U), thorium (Th) and potassium (K) concentrations were measured by Genalysis Laboratories, Perth, using Inductively Coupled Plasma Mass Spectroscopy (ICPMS) for U and Th, and Inductively Coupled Plasma Atomic Emission Spectrometry (ICPAES) for K. U and Th concentrations were also measured by thick source alpha counting (TSAC) in the Adelaide laboratory, and $\mathrm{K}$ concentrations by CSIRO laboratories, Adelaide, using X-ray fluorescence spectroscopy (XRS). The cosmic ray contribution was obtained using the relationship between cosmic ray penetration, depth and latitude determined by (Prescott and Hutton, 1994). The radionuclide concentrations obtained by the various methods were averaged, and the dose rate to be used in the age calculation, as well as the beta and gamma contributions to this dose rate, was determined using the AGE program of Grün (see Grün (2009)).

In Aberystwyth, beta dose rate was determined using a Risø beta counter (BøtterJensen and Mejdahl, 1988), and the concentration of $\mathrm{U}$, Th and $\mathrm{K}$ in the samples was determined using geochemical methods. For each sample, a finely milled sub-sample was fused using a sodium metaborate flux and put into solution. The resulting solutions were analysed using ICP-OES to determine the concentration of K and ICP-MS to determine the concentration of $\mathrm{U}$ and Th. The conversion factors of Adamiec and Aitken (1998) were then used to calculate the gamma dose rate. The cosmic ray contribution was obtained using the relationship between cosmic ray penetration, depth and latitude determined by Prescott and Hutton (1994). Water content of the material as received was measured by weighing, drying overnight at $180^{\circ} \mathrm{C}$, and re-weighing. A value of $5 \pm 2 \%$ was used as the best estimate of the 
water content during the period of burial for all samples except the sample from the modern

124 White Nile where a value of $10 \pm 5 \%$ was used (Note: an increase of $1 \%$ in the water content causes an increase of approximately $1 \%$ in the measured age of the sample). The results of

126 these measurements, and the calculated dose rates, are given in Table S3. Adelaide, and the other six samples including the surface sample were measured at the Aberystwyth Luminescence Research Laboratory (ALRL) at Aberystwyth University.

Luminescence measurements in Adelaide

In Adelaide luminescence measurements were made on small aliquots consisting of between about 50 to 100 grains in the $125-180 \mu \mathrm{m}$ range. Pilot studies had indicated that this number of grains would enable individual differences between the aliquots to be detected, while still providing measurable luminescence. Luminescence measurements were carried out using a Risǿ TL/OSL-DA-20 reader. Radiation was applied using a calibrated ${ }^{90} \mathrm{Sr} /{ }^{90} \mathrm{Y} \beta$ source delivering a dose rate of $0.135 \mathrm{~Gy} / \mathrm{sec}$. Luminescence was stimulated using blue lightemitting diodes (wavelength $470 \mathrm{~nm}$ ) and detected using an EMI 9235QB photomultiplier and

138 Hoya U340 filter. The measurement procedure followed the single aliquot regeneration

139 (SAR) protocol described by Murray and Wintle (2000). Four regeneration doses were used,

140 selected on the basis of a pilot study, plus a zero dose point to test for recuperation, a repeat

141 of the first dose to test for acceptable recycling and a second repeat of the first dose followed

142 by exposure to infra-red radiation to test for the absence of feldspars (IR depletion test). 24

143 aliquots were run, and those having recycling ratios greater than 0.85 , recuperation less than

1440.15 and IR depletion ratio less than 0.15 were accepted for analysis. 23 out of the 24 aliquots

145 passed the screening criteria. The equivalent dose $D_{e}$ was determined for each aliquot by

146 interpolation of its dose response (luminescence vs dose) curve. The equivalent dose is the 
147 laboratory-applied dose that produces luminescence equal to that of the natural sample and is

148 hence equal to the total burial dose.

149 The individual $\mathrm{D}_{\mathrm{e}}$ values showed a fairly well constrained distribution with six clearly 150 outlying high values. The $\mathrm{D}_{\mathrm{e}}$ values were combined, omitting the outliers, using the central 151 age model (CAM) to derive a final $\mathrm{D}_{\mathrm{e}}$ value for age calculation.

\section{Luminescence measurements in Aberystwyth}

In Aberystwyth luminescence measurements were made on aliquots containing 500 grains of quartz between $180-211 \mu \mathrm{m}$ in diameter. A Risø TL/OSL reader model TL-DA-15 was used for measurements. Blue LEDs $(470 \Delta 20 \mathrm{~nm})$ were used for optical stimulation, and the resulting OSL was detected using an EMI 9635QA photomultiplier fitted with $7.5 \mathrm{~mm}$ of Hoya U-340 filter. The resulting OSL signals showed a rapid initial decrease in intensity (Fig. S1a) as would be expected from samples where the OSL signal is dominated by the fast component. As in Adelaide, the SAR method was used, and typically 6 to 7 regeneration

160 doses were used to characterise the dose response curve and calculate the equivalent dose

$161\left(D_{e}\right)$ for each aliquot (Fig. S1b). Uncertainties on individual $D_{e}$ values were determined using 162 the approach outlined in Duller (2007) which incorporates the uncertainty due to counting statistics on each individual OSL decay curve, the uncertainty in the curve fitting procedure, and also a $1.5 \%$ uncertainty associated with the Ris $\varnothing$ instruments used for these measurements. Twenty-four replicate measurements of $D_{e}$ were made for each sample. Data

166 was screened using standard acceptance criteria, including (1) a recycling ratio within $10 \%$ of

167 unity, (2) an IR depletion ratio (Duller, 2003) within 10\% of unity, (3) a net OSL signal from 168 the test dose that is at least three times larger than the standard deviation of the background,

169 (4) a dose response curve that increases monotonically and (5) a natural signal (and 170 associated uncertainty) that intersects with the dose response curve. This screening removed 171 very few aliquots, with between 21 and 24 aliquots passing all of these criteria. 

demonstrating that quartz is very effectively reset by exposure to daylight at the time of deposition in this environment. One of the limitations of luminescence dating is the impact of saturation of the OSL signal at high doses. The form of the dose response curve (Fig. S1b) is either a single saturating exponential, or the sum of two saturating exponential functions. As the radiation dose to which a sample is exposed increases, the rate of growth of the OSL signal decreases, until at some point there is negligible growth. Beyond this point it is not possible to resolve samples of different age. A number of the samples in this study have large

$180 \mathrm{D}_{\mathrm{e}}$ values (> $100 \mathrm{~Gy}$, Table S4), but no more than 2 aliquots from 24 measured for each 181 sample failed because the OSL signal was saturated. However, one feature of the samples 182 with a high $\mathrm{D}_{\mathrm{e}}(>100 \mathrm{~Gy})$ is that they tend to have dose distributions (Fig. S1c) with overdispersion values (25-30\%) slightly higher than is normally encountered in younger samples, and this is thought to result from curvature of the dose response curve. There is no evidence that this overdispersion is related to incomplete resetting of the luminescence signal at deposition, and the age of $0 \pm 21$ years for the modern sample supports this. Therefore, the $D_{e}$ values for each sample were combined using the central age model (CAM) to derive a final $D_{e}$ value for age calculation. The equivalent doses, dose rates and ages for all the luminescence samples are summarised in Table S4.

\section{LAKE RECONSTRUCTION} horizontal resolution and a $\sim 5 \mathrm{~m}$ vertical precision in this region, and was used to map the White Nile River valley in ARCGIS (Fig. 1). Palaeoshorelines are obvious in many areas and were mapped directly from the DEM. The height of the shoreline drops by $\sim 5 \mathrm{~m}$ over a distance of $400 \mathrm{~km}$, indicating a gradient of $\sim 1: 80,000$. This is due to incomplete damming of the lake. Contours were generated at $395 \mathrm{~m}$ in the lower catchment and $400 \mathrm{~m}$ in the upper 
197 catchment, which showed the best fit to the top of the shorelines. This allowed for the 198 shoreline of the entire lake to be extrapolated to where shorelines were absent. The area and 199 volume of the palaeolake were calculated in GIS by filling the valley to the appropriate 200 height, whilst taking into account the underlying topography. 
203

204

205

206

207

208

209

210

211

212

213

214

215

216

217

218

219

220

221

222

223

224

225

226

227

228

229

230

231

232

233

234

235

236

237

238

239

240

241

242

243

244

245

246

247

248

249

250

Adamiec, G., and Aitken, M. J., 1998, Dose-rate conversion factors: update: Ancient TL v. 16 , no. 2, p. 37-50.

Balco, G., Briner, J., Finkel, R. C., Rayburn, J. A., Ridge, J. C., and Schaefer, J. M., 2009, Regional beryllium-10 production rate calibration for late-glacial northeastern North America: Quaternary Geochronology, v. 4, no. 2, p. 93-107.

Balco, G., Stone, J. O., Lifton, N. A., and Dunai, T. J., 2008, A complete and easily accessible means of calculating surface exposure ages or erosion rates from $10 \mathrm{Be}$ and 26Al measurements: Quaternary Geochronology, v. 3, no. 3, p. 174-195.

Barrows, T. T., Stone, J. O., Fifield, L. K., and Cresswell, R. G., 2001, Late Pleistocene Glaciation of the Kosciuszko Massif, Snowy Mountains, Australia: Quaternary Research, v. 55, no. 2, p. 179-189.

Barrows, T. T., Almond, P., Rose, R., Keith Fifield, L., Mills, S. C., and Tims, S. G., 2013, Late Pleistocene glacial stratigraphy of the Kumara-Moana region, West Coast of South Island, New Zealand: Quaternary Science Reviews, v. 74, no. 0, p. 139-159.

Bierman, P. R., and Caffee, M., 2002, Cosmogenic exposure and erosion history of Australian bedrock landforms: Geological Society of America Bulletin, v. 114, no. 7, p. 787-803.

Bøtter-Jensen, L., and Mejdahl, V., 1988, Assessment of beta dose-rate using a GM multicounter system: International Journal of Radiation Applications and Instrumentation. Part D. Nuclear Tracks and Radiation Measurements, v. 14, no. 1-2, p. 187-191.

Duller, G. A. T., 2003, Distinguishing quartz and feldspar in single grain luminescence measurements: Radiation Measurements, v. 37, no. 2, p. 161-165.

-, 2007, Assessing the error on equivalent dose estimates derived from single aliquot regenerative dose measurements: Ancient TL v. 25, p. 15-24.

Fenton, C. R., Hermanns, R. L., Blikra, L. H., Kubik, P. W., Bryant, C., Niedermann, S., Meixner, A., and Goethals, M. M., 2011, Regional 10Be production rate calibration for the past $12 \mathrm{ka}$ deduced from the radiocarbon-dated Grøtlandsura and Russenes rock avalanches at $69^{\circ} \mathrm{N}$, Norway: Quaternary Geochronology, v. 6, no. 5, p. 437452.

Granger, D. E., and Smith, A. L., 2000, Dating buried sediments using radioactive decay and muogenic production of 26Al and 10Be: Nuclear Instruments and Methods in Physics Research Section B: Beam Interactions with Materials and Atoms, v. 172, no. 1-4, p. 822-826.

Grün, R., 2009, The “Age” programme for the calculation of luminescence age estimates: Ancient TL v. 27, p. 45-46.

Kaplan, M. R., Strelin, J. A., Schaefer, J. M., Denton, G. H., Finkel, R. C., Schwartz, R., Putnam, A. E., Vandergoes, M. J., Goehring, B. M., and Travis, S. G., 2011, In-situ cosmogenic ${ }^{10} \mathrm{Be}$ production rate at Lago Argentino, Patagonia: Implications for lateglacial climate chronology: Earth and Planetary Science Letters, v. 309, no. 1â€"'2, p. 21-32.

Lifton, N. A., Bieber, J. W., Clem, J. M., Duldig, M. L., Evenson, P., Humble, J. E., and Pyle, R., 2005, Addressing solar modulation and long-term uncertainties in scaling secondary cosmic rays for in situ cosmogenic nuclide applications: Earth and Planetary Science Letters, v. 239, no. 1-2, p. 140-161.

Macklin, M. G., Woodward, J. C., Welsby, D. A., Duller, G. A. T., Williams, F. M., and Williams, M. A. J., 2013, Reach-scale river dynamics moderate the impact of rapid 
Holocene climate change on floodwater farming in the desert Nile: Geology, v. 41, no. 6, p. 695-698.

Murray, A. S., and Wintle, A. G., 2000, Luminescence dating of quartz using an improved single-aliquot regenerative-dose protocol: Radiation Measurements, v. 32, no. 1, p. 57-73.

Prescott, J. R., and Hutton, J. T., 1994, Cosmic ray contributions to dose rates for luminescence and ESR dating: Large depths and long-term time variations: Radiation Measurements, v. 23, no. 2-3, p. 497-500.

Putnam, A. E., Schaefer, J. M., Barrell, D. J. A., Vandergoes, M., Denton, G. H., Kaplan, M. R., Finkel, R. C., Schwartz, R., Goehring, B. M., and Kelley, S. E., 2010, In situ cosmogenic ${ }^{10} \mathrm{Be}$ production-rate calibration from the Southern Alps, New Zealand: Quaternary Geochronology, v. 5, no. 4, p. 392-409.

Stone, J. O., 2000, Air pressure and cosmogenic isotope production: Journal of Geophysical Research, v. 105, p. 23,753-723,759.

Williams, M. A. J., Williams, F. M., Duller, G. A. T., Munro, R. N., El Tom, O. A. M., Barrows, T. T., Macklin, M., Woodward, J., Talbot, M. R., Haberlah, D., and Fluin, J., 2010, Late Quaternary floods and droughts in the Nile valley, Sudan: new evidence from optically stimulated luminescence and AMS radiocarbon dating: Quaternary Science Reviews, v. 29, no. 9-10, p. 1116-1137. 
Supplemental Table S1. Site data

\begin{tabular}{ccccccc}
\hline Sample & $\begin{array}{c}\text { Longitude } \\
\left({ }^{\circ} \mathrm{N}\right)\end{array}$ & $\begin{array}{c}\text { Latitude } \\
\left({ }^{\circ} \mathrm{E}\right)\end{array}$ & $\begin{array}{c}\text { Altitude } \\
(\mathrm{m})\end{array}$ & $\begin{array}{c}\text { Horizon } \\
\text { correction }\end{array}$ & $\begin{array}{c}\text { Thickness/depth } \\
(\mathrm{cm})^{1}\end{array}$ & $\begin{array}{c}\text { Muon production rate } \\
\left(\text { atoms g }^{-1} \mathrm{yr}^{-1}\right)\end{array}$ \\
\hline Jebel Hawaja & & & & & & \\
JEB-01 & $12^{\circ} 35^{\prime} 33^{\prime \prime}$ & $32^{\circ} 50^{\prime} 8.1^{\prime \prime}$ & 426 & 1 & 3.0 & 0.210 \\
JEB-02 & $12^{\circ} 35^{\prime} 36^{\prime \prime}$ & $32^{\circ} 50^{\prime} 7.1^{\prime \prime}$ & 427 & 1 & 2.5 & 0.210 \\
JEB-03 & $12^{\circ} 35^{\prime} 4.0^{\prime \prime}$ & $32^{\circ} 50^{\prime} 6.8^{\prime \prime}$ & 425 & 1 & 3.0 & 0.210 \\
Jebelein shoreline & & & & & 0.209 \\
JEB-S06 & $12^{\circ} 35^{\prime} 7.5^{\prime \prime}$ & $32^{\circ} 49^{\prime} 55.9^{\prime \prime}$ & 402 & 1 & 2.5 & 55 \\
JEB-S05 & $12^{\circ} 35^{\prime} 7.5^{\prime \prime}$ & $32^{\circ} 49^{\prime} 55.9^{\prime \prime}$ & & 1 & 105 & 165 \\
JEB-S04 & $12^{\circ} 35^{\prime} 7.5^{\prime \prime}$ & $32^{\circ} 49^{\prime} 55.9^{\prime \prime}$ & & 1 & 205 & \\
JEB-S03 & $12^{\circ} 35^{\prime} 7.5^{\prime \prime}$ & $32^{\circ} 49^{\prime} 55.9^{\prime \prime}$ & & 1 & 275 & \\
JEB-S02 & $12^{\circ} 35^{\prime} 7.5^{\prime \prime}$ & $32^{\circ} 49^{\prime} 55.9^{\prime \prime}$ & & 1 & & \\
JEB-S01 & $12^{\circ} 35^{\prime} 7.5^{\prime \prime}$ & $32^{\circ} 49^{\prime} 55.9^{\prime \prime}$ & & 1 & & \\
\hline
\end{tabular}


277 Supplemental Table S2. ${ }^{10}$ Be results

\begin{tabular}{|c|c|c|c|c|}
\hline Sample & Lab code & $\begin{array}{c}\text { Production Rate } \\
\left(\text { atoms } \mathrm{g}^{-1} \mathrm{yr}^{-1} \text { ) }\right. \\
\text { Muons }\end{array}$ & $\begin{array}{c}\left.{ }^{10} \mathrm{Be}\right]_{\mathrm{c}} \\
\left(\mathrm{x} 10^{5} \mathrm{~g}^{-1}\right)\end{array}$ & $\begin{array}{l}\text { Weathering rate } \\
\qquad(\mathrm{m} / \mathrm{Ma})^{1}\end{array}$ \\
\hline
\end{tabular}

\section{Jebel Hawaja}

JEB-01

\section{JEB-02}

ANU-M392-02

$25.2 \pm 1.70$

$0.73 \pm 0.12$

JEB-02

ANU-M392-03

$9.90 \pm 0.70$

$2.64 \pm 0.33$

JEB-03

ANU-M392-04

$6.26 \pm 0.46$

$4.62 \pm 0.54$

Section $S 2$

JEB-S2-06a

ANU-M392-05

$5.01 \pm 0.21$

JEB-S2-06b

ANU-M430-11

$5.56 \pm 0.26$

JEB-S2-05

ANU-M430-10

$5.58 \pm 0.24$

JEB-S2-04

ANU-M430-09

$4.17 \pm 0.18$

JEB-S2-03

ANU-M430-08

$3.72 \pm 0.18$

ANU-M430-07

$3.88 \pm 0.18$

JEB-S2-01

ANU-M392-06

$3.30 \pm 0.14$

278 Data are normalised to NIST SRM 4325 assuming ${ }^{10} \mathrm{Be} /{ }^{9} \mathrm{Be}=2.79 \times 10^{-11}$.

279 Carrier ${ }^{10} \mathrm{Be} /{ }^{9} \mathrm{Be}=<1 \times 10^{-15} .{ }^{10} \mathrm{Be}$ decay constant $=4.998 \times 10^{-7} \mathrm{yr}^{-1}$.

280 Sample density for granite $=2.7 \mathrm{~g} \mathrm{~cm}^{-3}$

281 1. Calculated using CRONUS online calculator and Wrapper script: 2.2, Main calculator: 2.1, Objective function: 2.0, Constants: 2.2.1, and Muons: 1.1 versions 
Supplemental Table S3. Sample data for optical ages

\begin{tabular}{cccccccc}
\hline Site & Sample & Depth $(\mathrm{m})$ & Aliquots & $\mathrm{H}_{2} \mathrm{O} \%$ & $\mathrm{~K}(\%)$ & $\mathrm{U}(\mathrm{ppm})$ & $\mathrm{Th}(\mathrm{ppm})$ \\
\hline B & S11/1-1 & $1.20 \pm 0.10$ & 22 & $5 \pm 2$ & $1.10 \pm 0.06$ & $0.76 \pm 0.04$ & $2.59 \pm 0.13$ \\
B & S11/1-2 & $1.50 \pm 0.20$ & 23 & $5 \pm 2$ & $1.09 \pm 0.06$ & $0.67 \pm 0.03$ & $2.00 \pm 0.10$ \\
B & S11/1-3 & $2.35 \pm 0.50$ & 21 & $5 \pm 2$ & $0.97 \pm 0.05$ & $0.67 \pm 0.03$ & $1.82 \pm 0.09$ \\
C & S10/5-2 & $1.10 \pm 0.10$ & 22 & $5 \pm 2$ & $0.87 \pm 0.03$ & $1.03 \pm 0.07$ & $3.72 \pm 0.24$ \\
C & S10/5-3 & $1.50 \pm 0.10$ & 21 & $5 \pm 2$ & $0.90 \pm 0.05$ & $0.64 \pm 0.03$ & $1.78 \pm 0.09$ \\
C & S10/5-4 & $1.65 \pm 0.10$ & 24 & $5 \pm 2$ & $0.92 \pm 0.05$ & $0.67 \pm 0.03$ & $1.33 \pm 0.07$ \\
D & S11/3-1 & $0.80 \pm 0.50$ & 22 & $5 \pm 2$ & $0.93 \pm 0.05$ & $1.03 \pm 0.05$ & $1.14 \pm 0.06$ \\
E & S11/WN1 & $0.00 \pm 0.10$ & 24 & $10 \pm 5$ & $0.97 \pm 0.05$ & $0.56 \pm 0.03$ & $0.78 \pm 0.04$ \\
\hline
\end{tabular}




\section{Supplemental Table S4. Dose and dose rates for optical ages}

\begin{tabular}{cccccccc}
\hline & & $\begin{array}{c}\text { External } \beta \\
\text { dose 'wet' } \\
\text { (Gy/ka) }\end{array}$ & $\begin{array}{c}\text { External } \gamma \\
\text { dose 'wet' } \\
\text { (Gy/ka) }\end{array}$ & $\begin{array}{c}\text { Cosmic } \\
\text { dose } \\
\text { (Gy/ka) }\end{array}$ & $\begin{array}{c}\text { Total dose } \\
\text { rate (Gy/ka) }\end{array}$ & $\begin{array}{c}\text { Equivalent } \\
\text { dose (Gy) }\end{array}$ & Age (ka) \\
\hline B & S11/1-1 & $0.99 \pm 0.04$ & $0.45 \pm 0.02$ & $0.18 \pm 0.02$ & $1.62 \pm 0.05$ & $112 \pm 6.2$ & $69 \pm 4$ \\
B & S11/1-2 & $0.90 \pm 0.04$ & $0.41 \pm 0.02$ & $0.17 \pm 0.02$ & $1.48 \pm 0.04$ & $130 \pm 6.2$ & $88 \pm 5$ \\
B & S11/1-3 & $0.83 \pm 0.04$ & $0.38 \pm 0.02$ & $0.16 \pm 0.04$ & $1.36 \pm 0.06$ & $140 \pm 10$ & $103 \pm 9$ \\
C & S10/5-2 & $0.79 \pm 0.05$ & $0.48 \pm 0.05$ & $0.19 \pm 0.02$ & $1.47 \pm 0.04$ & $15.3 \pm 1.5$ & $10.4 \pm 1.1$ \\
C & S10/5-3 & $0.71 \pm 0.03$ & $0.36 \pm 0.02$ & $0.17 \pm 0.02$ & $1.24 \pm 0.03$ & $141 \pm 9.6$ & $113 \pm 8$ \\
C & S10/5-4 & $0.85 \pm 0.04$ & $0.34 \pm 0.01$ & $0.17 \pm 0.02$ & $1.36 \pm 0.04$ & $156 \pm 13$ & $115 \pm 10$ \\
D & S11/3-1 & $0.80 \pm 0.03$ & $0.38 \pm 0.02$ & $0.19 \pm 0.04$ & $1.36 \pm 0.05$ & $142 \pm 7.0$ & $104 \pm 6$ \\
& & & & & & & \\
E & S11/WN1 & $0.65 \pm 0.04$ & $0.30 \pm 0.02$ & $0.30 \pm 0.03$ & $1.25 \pm 0.06$ & $0.00 \pm 0.02$ & $0.00 \pm 0.02$ \\
\hline
\end{tabular}

Note:

Grain Size $180-211 \mu \mathrm{m}$ for all samples except S10/5-2 for which grains $150-180 \mu \mathrm{m}$ in diameter were used. 
Figure S1: Luminescence characteristics of a typical sample (S10/5-3). (a) Natural OSL decay curve. Note the log scale on the y-axis, (b) dose response curve and (c) radial plot showing the distribution of $\mathrm{D}_{\mathrm{e}}$ values.

(a)

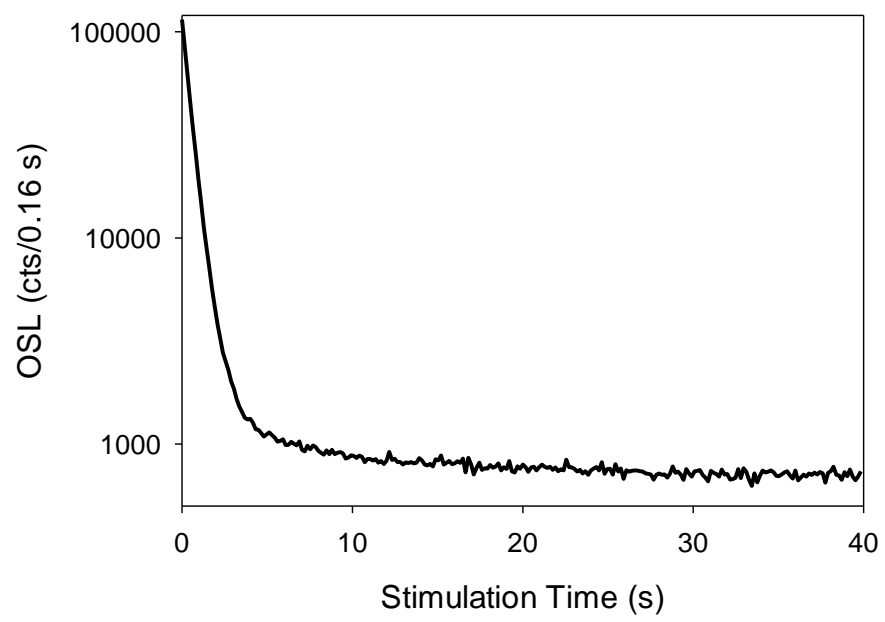

(b)

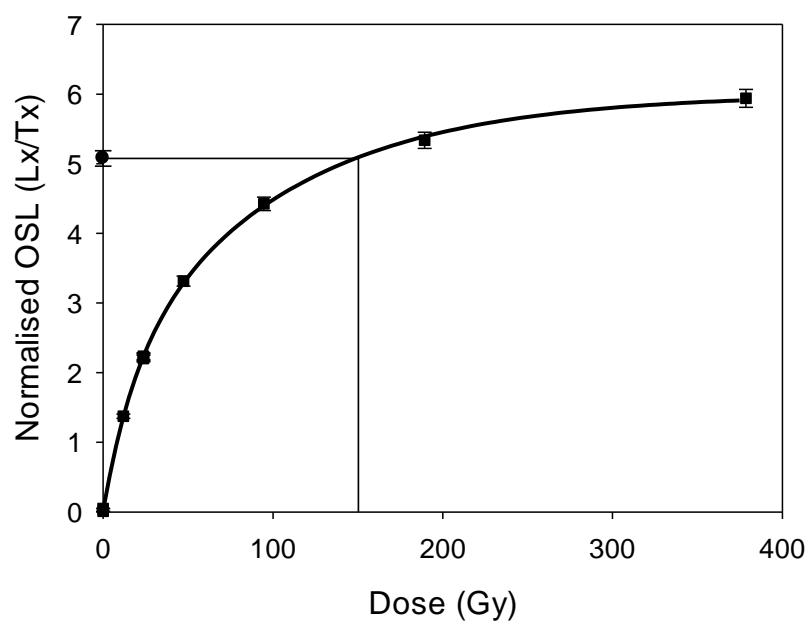

(c)
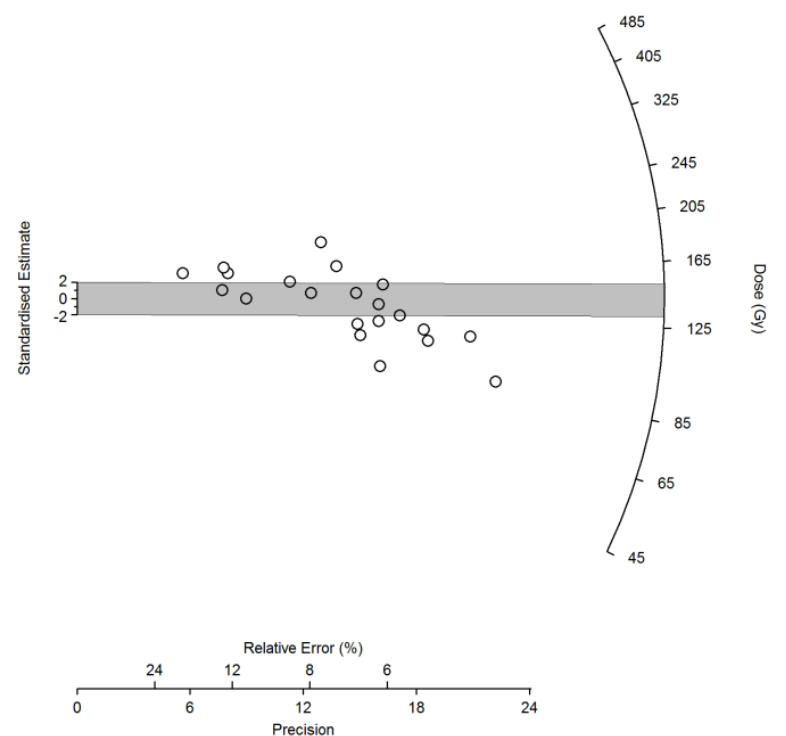
